\title{
Immunohistochemical Evaluation of Canine Ovarian Tumors
}

\author{
Yuko AKIHARA ${ }^{1)}$, Yumiko SHIMOYAMA ${ }^{1)}$, Kazufumi KAWASAKO ${ }^{1)}$, Misa KOMINE ${ }^{1)}$, Kazuko HIRAYAMA ${ }^{1)}$, \\ Yumiko KAGAWA ${ }^{2)}$, Tetsuo OMACHI ${ }^{3)}$, Kazuya MATSUDA ${ }^{1)}$, Minoru OKAMOTO ${ }^{1)}$, Tsuyoshi KADOSAWA ${ }^{4)}$ and \\ Hiroyuki TANIYAMA ${ }^{1) *}$
}

${ }^{1)}$ Departments of Veterinary Pathology and ${ }^{4}$ Small Animal Clinical Sciences, School of Veterinary Medicine, Rakuno Gakuen University, 582 Bunkyodai-Midorimachi, Ebetsu, Hokkaido 069-8501, ${ }^{2}$ NORTH LABO, Sapporo, Hokkaido 004-0071 and ${ }^{3)}$ PATHO LABO, Shizuoka 413-0235, Japan

(Received 20 October 2006/Accepted 13 March 2007)

\begin{abstract}
Canine ovarian tumors (epithelial tumor, sex-cord stromal tumor, germ cell tumor) classifying into 9 histological types were examined immunohistochemically using placental alkaline phosphatase (PLAP), cytokeratin7 (CK7), desmin, S100, AE1/AE3, inhibin $\alpha$, vimentin, and alfa feto-protein (AFP). The papillary and tubular types observed in epithelial tumors were immunoreactive for desmin and AE1/AE3. The papillary type was also immunoreactive for PLAP and CK7. The solid type, nest type, cord type, palisade type, cystic type and spindle type, which were observed in sex-cord stromal tumors, showed a positive immunoreaction for S100 but little or no positive immunoreaction for inhibin $\alpha$ with an exception of positive result in the palisade type. Most of the sex-cord stromal tumors were AE1/AE3-positive except for the palisade type. In the cobblestone type observed in germ cell tumors, only vimentin and AFP were positive. The present study elucidated the detailed histological and immunohistochemical characteristics of canine ovarian tumors. KEY WORDS: canine, immunohistochemistry, ovarian tumor.
\end{abstract}

J. Vet. Med. Sci. 69(7): 703-708, 2007

In human, primary ovarian tumors have been divided into 6 categories: surface epithelial-stromal tumors, sex cordstromal tumors, germ cell tumors, germ cell-sex cord-stromal tumors, tumors of rete ovarii and miscellaneous tumors, according to the WHO classification [17]. In dog, the primary ovarian tumors are divided into 4 categories: epithelial tumors, sex cord-stromal tumors, germ cell tumors and mesenchymal tumors, according to the WHO classification of domestic animals [4]. The WHO classification of human primary ovarian tumors has further classified each category in detail into histological types based on the morphological similarities. For each histological type, the prognosis or drug response was examined, and these data are used to provide the pertinent treatment [17]. However, the WHO classification of dog (animal) primary ovarian tumors is quite broad, and the classification of a detailed histological type has not been completed.

The canine ovary shows a complicated histology because of its distinctive structure of cortical tubules and granular cell cord. Therefore, if tumor proliferation occurs in a canine ovary, a variety of histologies may emerge because of the proliferation of the complex structure itself or of the neoplastic cells involved within the complex structure. Thus, a pathologist may sometimes find it difficult to diagnose a canine ovarian tumor. Patneik [14] investigated canine ovarian tumors retrospectively and reported the various histologies seen in a sex cord-stromal tumor. However, to our knowledge, there have been no results dealing with

\footnotetext{
* Correspondence to: Taniyama, H., Department of Veterinary Pathology, School of Veterinary Medicine, Rakuno Gakuen University, 582 Bunkyodai-Midorimachi, Ebetsu, Hokkaido 0698501, Japan.

e-mail: taniyama@rakuno.ac.jp
}

the histological classification of canine ovarian tumors by use of immunohistochemistry. Therefore, in the present study, we investigated in detail the respective histological types for epithelial tumor, sex cord-stromal tumor and germ cell tumors, and examined the immunohistochemical characteristics in each of 3 cases from the nine different histological types.

\section{MATERIALS AND METHODS}

Canine ovarian tumor samples were fixed in $10 \%$ buffered formalin for histopathological and immunohistochemical studies. They were then trimmed, embedded in paraffin, sectioned at $4 \mu \mathrm{m}$, and stained with hematoxylin and eosin (HE). After histopathological diagnosis, these samples were classified into the nine histological types based on the morphological similarity, and then 3 cases of each histological type were selected for the immunohistochemical examinations. Contiguous sections were immunohistochemically examined by the avidin-biotin-peroxidase complex (ABC) procedure (Vectastain Elite ABC Kit; Vector Laboratories, Burlingame, CA, U.S.A.). Primary antibodies used in this study were placental alkaline phosphatase (PLAP), cytokeratin7 (CK7), desmin, S100, AE1/AE3, inhibin $\alpha$, vimentin and alfa feto-protein (AFP) (Table 1). The blocking of endogenous peroxidase was done with $0.3 \% \mathrm{H}_{2} \mathrm{O}_{2}$ in methanol for $10 \mathrm{~min}$. All sections were incubated with primary antibody at $4{ }^{\circ} \mathrm{C}$ for $16 \mathrm{hr}$, with biotinylated secondary antibody for $30 \mathrm{~min}$ at room temperature, and with avidinperoxidase conjugate for $30 \mathrm{~min}$. Staining was developed in $0.05 \% 3,3$ '-diaminobenzidine solution. Ovaries from 5 dogs with no gross lesions were also used as a control. As a negative control, a section incubated without the primary 
Table 1. Primary antibodies used for immunohistochemical labelling

\begin{tabular}{llcll}
\hline Antibody & Type & Dilution & Pretreatment & Source \\
\hline PLAP $^{\text {a }}$ & $\mathrm{mAb}^{\mathrm{d})}$ & $1: 50$ & microwave & Dako, Demmark \\
$\mathrm{CK}^{\mathrm{b}}$ ) & $\mathrm{mAb}$ & $1: 50$ & pepsin & Dako, Demmark \\
desmin & $\mathrm{mAb}$ & $1: 50$ & microwave & Progen \\
$\mathrm{S} 100$ & $\mathrm{pAb}^{\mathrm{e}}$ & $1: 2000$ & microwave & Dako, Demmark \\
inhibin $\alpha$ & $\mathrm{mAb}$ & $1: 50$ & microwave & Serotec, Kidlington, \\
& & & & Oxford, UK \\
$\mathrm{AE} 1 / \mathrm{AE} 3$ & $\mathrm{mAb}$ & prediluted & microwave & Nichirei, Tokyo, Japan \\
vimentin & $\mathrm{mAb}$ & $1: 100$ & microwave & Progen \\
$\mathrm{AFP}$ ) & $\mathrm{pAb}$ & $1: 100$ & microwave & Dako, Demmark \\
\hline
\end{tabular}

a) PLAP, placental alkaline phosphatase. b) CK7, cytokeratin 7. c) AFP, alpha feto-protein. d) mAb, monoclonal antibody. e) pAb, polyclonal antibody.

antibody was investigated in the same way.

The immunohistochemical results were expressed semiquantitatively as follows: - , negative;,$+<10 \%$ positive cells;,$++ 10-70 \%$ positive cells; and,$+++>70 \%$ positive cells.

\section{RESULTS}

\section{Histological findings}

Epithelial tumor: Adjacent to the surface epithelium, neoplastic cells which have a pyknotic nucleus with scarce cytoplasm and form arboriform papillae were observed (Fig. 1a). Histological diagnoses of these tumors were all papillary carcinoma. Slightly large-sized cells with eosinophilic cytoplasm and ovoid nucleus forming tubelike structures in shallow cortex were also observed (Fig. 1b). Histological diagnoses of these tumors were papillary cystadenoma (dog no. $2 \mathrm{a}$ ) and papillary adenoma (dog no. $2 \mathrm{~b}$ and $2 \mathrm{c}$ ) respectively. As histological types, they were grouped into papillary (Fig. 1a) and tubular types (Fig. 1b).

Sex cord-stromal tumor: All sex cord-stromal tumors were diagnosed as granulosa cell tumor. The neoplastic cells, which had an ellipsoid nucleus, eosinophilic cytoplasm and no clear cell border, were sometimes proliferating densely in the tissue without showing any particular pattern. They were classified as solid type (Fig. 1c). There were a few to several dozen cells which had an ovoid nucleus with a clear small nucleolus with bright cytoplasm and demarcated by thin connective tissue. These were classified as nest type (Fig. 1d). In the cord type, there was proliferation of cells with the ovoid nucleus having a clear small nucleolus and eosinophilic to amphophilic cytoplasm. These cells were lined up perpendicularly against basal lamina and resembling a granular cell cord or Sertoli cells (Fig. 1e). In the palisade type, there was proliferation of cells with an ovoid nucleus having a clear medium-sized nucleous with thin eosinophilic cytoplasm. These cells were radially arranged around blood vessels and stroma (Fig. 1f). In the cyst type, there was proliferation of cells having an ovoid nucleus with a clear small nucleolus and eosinophilic cytoplasm. Individual neoplastic cells were overlapping each other and proliferated as a sheet, sometimes forming a small or large cyst which contained eosinophilic fluid (Fig.
$1 \mathrm{~g})$. In the spindle type, there was proliferation of neoplastic cells having oval nucleus and eosinophilic cytoplasm with high density. These were similar to solid-type cells, but individual cells were spindle-shaped and classified as spindle type (Fig. 1h).

Germ cell tumor: All germ cell tumors were diagnosed as dysgerminoma. These cells have a polygonal nucleus with a clear large prominent nucleolus and slightly eosinophilic cytoplasm. They were roughly demarcated as several or more cells by thin connective tissue, and were classified as cobblestone type (Fig. 1i).

Immunohistochemical findings (Table 2)

Epithelial tumor: All cases of papillary type and tubular type were positive for AE1/AE3 (Fig. 2a) and desmin (Fig. $2 \mathrm{~b})$. All cases of papillary type and 1 of 3 cases of tubular type were positive for PLAP (Fig. 2c) and CK7 (Fig. 2d). For S100, 1 of 3 of both histological types were positive. For vimentin, all of both histological types were positive. For AFP, 1 of 3 of papillary type and 1 of 2 of tubular type showed a positive immunoreaction in a few neoplastic cells. Either histological type of epithelial tumors was negative for inhibin $\alpha$.

Sex cord-stromal tumor: In all histological types of sex cord-stromal tumor, an S100-positive immunoreaction was observed in various numbers of tumor cells (Fig. 3a, 3d). For desmin, in all histological types, positive immunoreactions were observed in a small number of tumor cells. In palisade type, a large number of tumor cells were positive for inhibin $\alpha$ (Fig. 3b), but in other types of sex cord-stromal tumor, many or all tumor cells were negative (Fig. 3e). On the other hand, for palisade-type, all tumor cells were negative for AE1/AE3 (Fig. 3c), whereas in other types of sexcord stromal tumor, many tumor cells were positive (Fig. 3f). Positive reaction to AE1/AE3 was observed as a dotlike pattern. For vimentin, all tumor types were positive. For AFP, 1 of 3 of solid and cyst showed positive in a few neoplastic cells. All histological types in the sex-cord stromal tumor were negative for PLAP and CK7.

Germ cell tumor: All cases of cobblestone-type histology were positive for vimentin (Fig. 4a). For AFP, 1 of 3 cases indicated a positive immunoreaction in several neoplastic cells (Fig. 4b). The germ cell tumor was negative or almost negative for either PLAP, CK7, desmin, S100, AE1/AE3 or 

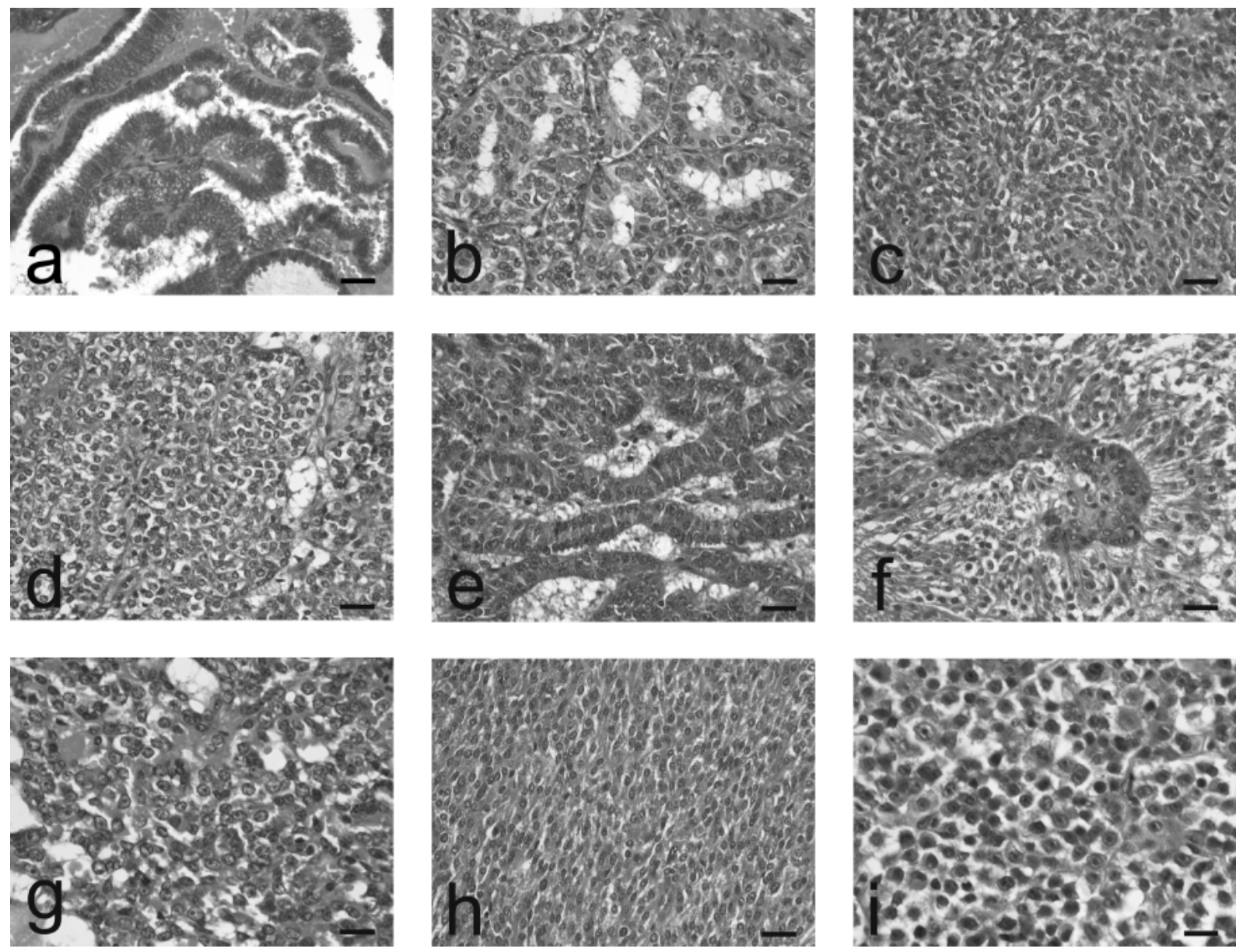

Fig. 1. Histological subtypes: papillary type (a), tubular type (b), solid type (c), nest type (d), code type (e), palisade type (f), cyst type (g), spindle type (h), cobblestone type (i). Hematoxylin and eosin stain. Bar $=30 \mu \mathrm{m}$.

inhibin $\alpha$.

\section{DISCUSSION}

From the present results, immunohistochemical characteristics were found in various histological types of canine ovarian tumor. In epithelial tumors, positive staining of desmin and AE1/AE3 was observed in the papillary type and tubular type. In a normal canine ovary, desmin becomes positive in epithelial structure as like as AE1/AE3. Desmin has been reported to recognize mesothelial cells in human [2] and ovarian surface epithelium in dog [19]. Moreover, desmin was positive in the surface epithelium, most cortical tubules, rete ovarii and part of fallopian tubes in the present study (data not shown). From these findings, the epithelial cells that are desmin-positive may reveal a coelomic epithelium origin. On the other hand, a positive immunoreaction for AE1/AE3 is known not only in epithelial tumors but also in sex cord-stromal tumors $[1,9,12,14]$, while in the present study a positive immunoreaction was also recognized in many types of sex cord-stromal tumors except the palisade type. From these findings, desmin was considered to be more useful than AE1/AE3 to distinguish sex-cord stromal tumors from epithelial tumors. A few positive immunoreactions to desmin were also observed in a sex cord-stromal tumor, but these positive findings were ascribed to the epithelial components of cortical tubules or surface epithelium.

In papillary-type tissue, CK7 and PLAP became specifically positive, and the results might be useful for the further characterization of the tumor. As for CK7 [9] and PLAP $[10,18]$, positive immunoreactions in ovary tumors have been reported. Moreover, in our findings, an especially PLAP-positive immunoreaction was observed only in the surface epithelium and part of the cortical tubules (data not shown). This is considered a substantial evidence to show that the papillary-type tumor may originate from surface epithelium or cortical tubules.

Sex cord-stromal tumors diagnosed as granulosa cell tumor were grouped further into six histological types (solid, nest, cord, palisade, cyst and spindle). As Patneik et al. reported [14], a mixture of different histological types was seen within a single tumor. Although palisade type had only a single histology, the other five histological types co- 
Table 2. Immunohistochemical results in ovarian tumors

\begin{tabular}{|c|c|c|c|c|c|c|c|c|c|c|}
\hline \multirow{2}{*}{$\begin{array}{l}\text { Tumor } \\
\text { type }\end{array}$} & \multirow{2}{*}{$\begin{array}{l}\text { Histology } \\
\text { (pattern) }\end{array}$} & \multirow[b]{2}{*}{ dog no. } & \multicolumn{8}{|c|}{ Target antigen } \\
\hline & & & PLAP $^{\text {a) }}$ & $\mathrm{CK} 7^{\mathrm{b})}$ & desmin & S100 & inhibin $\alpha$ & AE1/AE3 & vimentin & $\mathrm{AFP}^{\mathrm{c})}$ \\
\hline \multirow{6}{*}{$\begin{array}{l}\text { Epithelial } \\
\text { tumor }\end{array}$} & \multirow[t]{3}{*}{ papillary } & 1a & $\left.++^{e}\right)$ & +++ & ++ & ++ & - & +++ & ++ & - \\
\hline & & $1 b$ & ++ & ++ & ++ & - & - & ++ & ++ & + \\
\hline & & $1 \mathrm{c}$ & ++ & + & +++ & - & - & ++ & +++ & - \\
\hline & \multirow[t]{3}{*}{ tubular } & $2 a$ & + & + & ++ & - & - & +++ & +++ & $\mathrm{ND}^{\mathrm{d})}$ \\
\hline & & $2 b$ & - & - & ++ & ++ & - & +++ & +++ & + \\
\hline & & $2 \mathrm{c}$ & - & - & + & - & - & +++ & ++ & - \\
\hline \multirow{18}{*}{$\begin{array}{l}\text { Sex-cord } \\
\text { stromal } \\
\text { tumor }\end{array}$} & \multirow[t]{3}{*}{ solid } & $3 a$ & - & - & + & + & + & +++ & ++ & - \\
\hline & & $3 b$ & - & - & + & ++ & + & ++ & ++ & - \\
\hline & & $3 c$ & - & - & + & + & + & +++ & ++ & + \\
\hline & \multirow[t]{3}{*}{ nest } & $4 a$ & - & - & + & + & + & +++ & +++ & - \\
\hline & & $4 b$ & - & - & - & ++ & + & +++ & ++ & - \\
\hline & & $4 \mathrm{c}$ & - & - & - & +++ & + & +++ & ++ & ND \\
\hline & \multirow{3}{*}{ cord } & $5 a$ & - & - & + & + & - & +++ & ++ & - \\
\hline & & $5 b$ & - & - & + & + & - & +++ & +++ & - \\
\hline & & $5 c$ & - & - & + & + & - & ++ & ++ & - \\
\hline & \multirow[t]{3}{*}{ palisade } & $6 \mathrm{a}$ & - & - & - & ++ & +++ & - & +++ & ND \\
\hline & & $6 \mathrm{~b}$ & - & - & + & +++ & +++ & - & +++ & + \\
\hline & & $6 c$ & - & - & - & +++ & +++ & - & +++ & - \\
\hline & \multirow[t]{3}{*}{ cystic } & $7 \mathrm{a}$ & - & - & + & + & + & + & +++ & ND \\
\hline & & $7 b$ & - & - & + & ++ & + & ++ & +++ & - \\
\hline & & $7 \mathrm{c}$ & - & - & + & ++ & + & ++ & +++ & + \\
\hline & \multirow[t]{3}{*}{ spindle } & $8 \mathrm{a}$ & - & - & + & ++ & - & ++ & ++ & - \\
\hline & & $8 \mathrm{~b}$ & - & - & + & ++ & - & +++ & +++ & - \\
\hline & & $8 c$ & - & - & + & ++ & - & - & + & - \\
\hline \multirow{3}{*}{$\begin{array}{l}\text { Germ cell } \\
\text { tumor }\end{array}$} & \multirow[t]{3}{*}{ cobblestone } & $9 a$ & - & - & - & - & - & - & + & - \\
\hline & & $9 b$ & - & - & + & - & - & - & +++ & - \\
\hline & & $9 \mathrm{c}$ & - & - & - & - & - & - & ++ & ++ \\
\hline
\end{tabular}

a) PLAP, placental alkaline phosphatase. b) CK7, cytokeratin 7. c) AFP, alpha feto-protein. d) ND, not done. e) -, negative,,$+<10 \%$ positive cells,,$++ 10-70 \%$ positive cells,,$+++>70 \%$ positive cells.
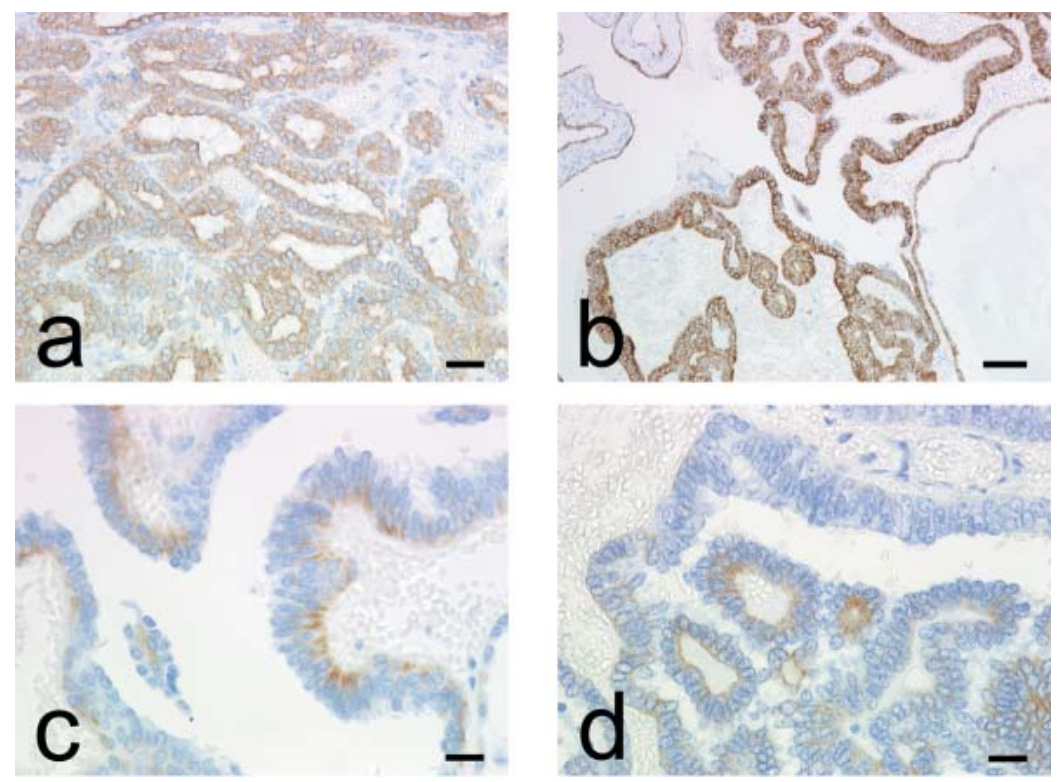

Fig. 2. Immunohistochemistry for AE1/AE3, desmin, placental alkaline phosphatase (PLAP) and cytokeratin 7 (CK7) in ovarian epithelial tumors: AE1/AE3 (a) and desmin (b) positive immunoreactions are observed in tubular type as well as in papillary type. PLAP (c) and CK7 (d) positive immunoreactions are observed in papillary type. Bars: $=50 \mu \mathrm{m} ; \mathrm{b}=100 \mu \mathrm{m} ; \mathrm{c}$ and $\mathrm{d}=30 \mu \mathrm{m}$. 

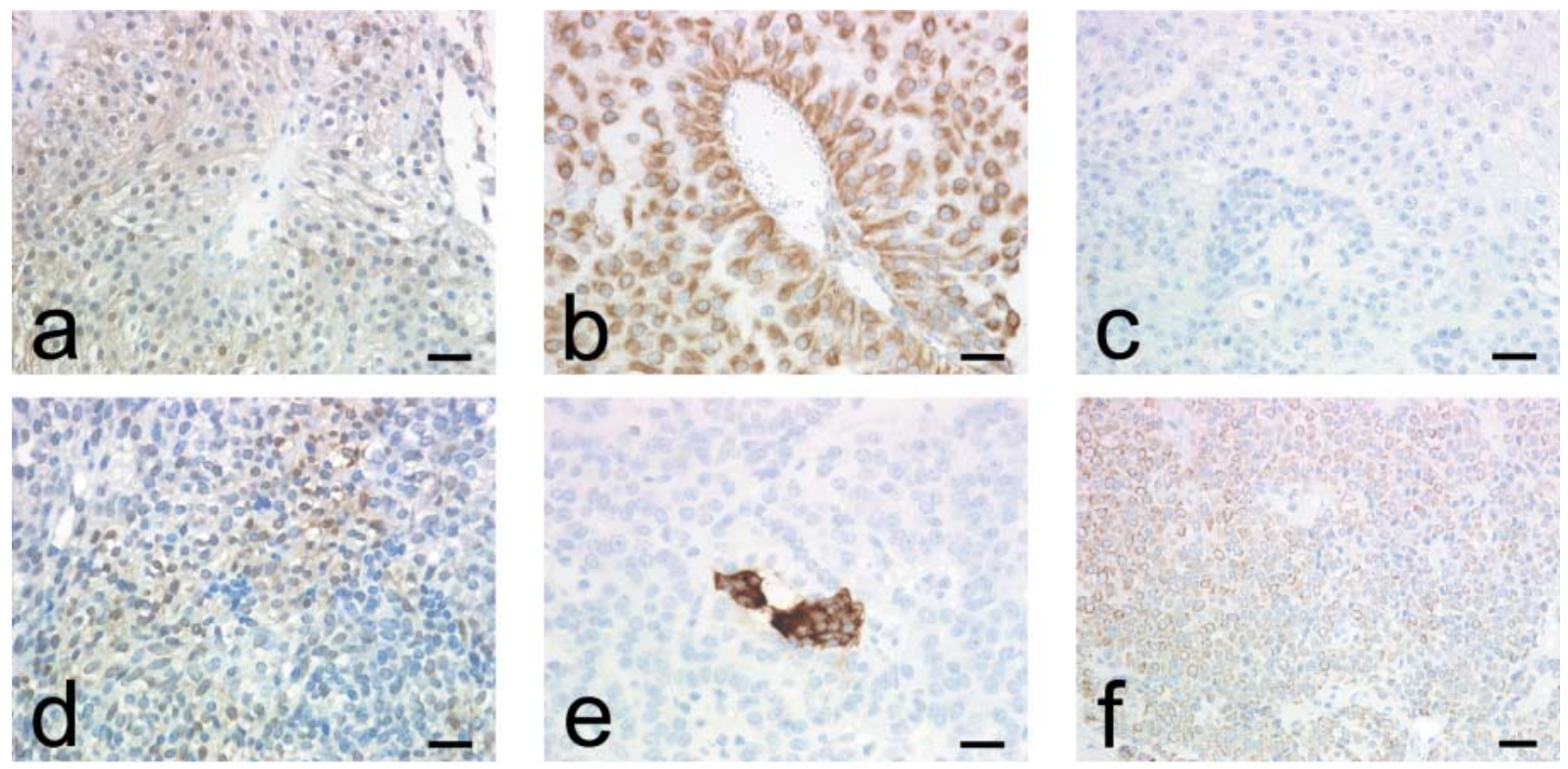

Fig. 3. Immunohistochemistry for S100, inhibin- $\alpha$ and AE1/AE3 in spindle type of ovarian sex cord-stromal tumors and other types of ovarian sex cord-stromal tumors: S100 (a and d), inhibin $\alpha$ (b and e) and AE1/AE3 (c and f). Both histological types are positive to S100. In palisade type, neoplastic cells are positive to inhibin $\alpha$ and negative for AE1/AE3, on the other hand, in other histological types, neoplastic cells are few positive to inhibin $\alpha$ and positive for AE1/AE3. Bars: $\mathrm{a}, \mathrm{c}$ and $\mathrm{f}=50 \mu \mathrm{m} ; \mathrm{b}, \mathrm{d}$ and $\mathrm{e}=30 \mu \mathrm{m}$.
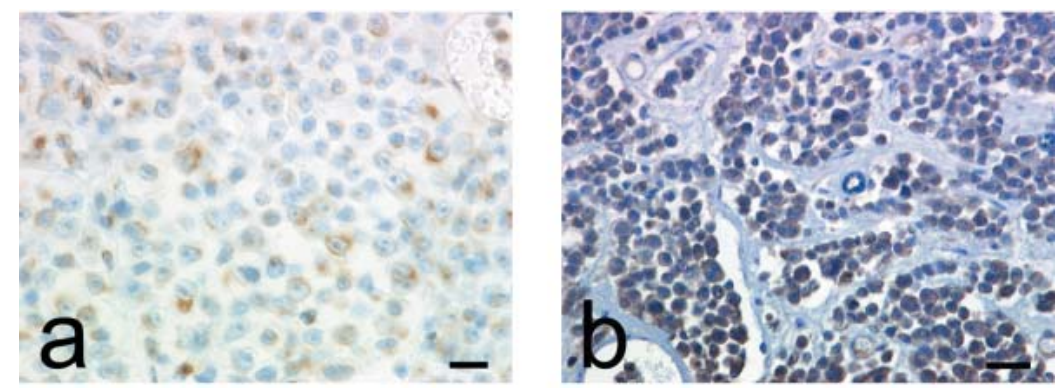

Fig. 4. Immunohistochemistry for vimentin and alpha-feto protein (AFP) in ovarian germ cell tumors: several neoplastic cells are positive to vimentin (a) and AFP (b). Bars: $\mathrm{a}=20 \mu \mathrm{m} ; \mathrm{b}=30 \mu \mathrm{m}$.

existed in complex histology. For example, spindle, solid and nest had cyst-type histology in part of the tumor, and cord type tumor existed with solid-type histology. However, it was not shown if similarly shaped cells exhibited the same immunoreaction. This reflects the fact that one tumor type can show different histological features [13]. It may also indicate that a sex cord-stromal tumor can be comprised of various cells with potency to differentiate in different way; or that tumor cells with different character or origin can proliferate at the same time $[3,6,7,11,15]$. In the palisade type, there were clearly more positive immunoreactive cells for inhibin $\alpha$ than any other histological type, and no positive immunoreaction for AE1/AE3 such as widely observed in other histological types. Given the immunohistochemical traits of the granulosa cell layer and granulosa cell cord in canine normal ovary, the palisade type may be of more differentiated than other subtypes.
The origins of sex cord-stromal cells are reportedly mesenchymal cells such as granulosa cell layer, granulosa cell cord, theca cells and fibroblast [4]. Sex cord-stromal tumors in human and dog are generally characterized by the fact that they are inhibin $\alpha$-positive $[8,16]$. In the present study, the positive immunoreaction for inhibin $\alpha$ was extremely limited except in the palisade type. When we compare histological findings observed in this investigation with a human ovarian tumor [17], the nest type resembled thecoma, the cord type resembled Sertoli-Leidig tumor of intermediate differentiation, and the solid type resembled a stromal tumor with minor sex cord elements. Based on the foregoing, three reasons were thought to explain the poor reaction to inhibin $\alpha: 1)$ low neoplastic cell differentiation; 2) cell proliferation involvement of other than the granulosa layer; and 3) strong participation of a hormone other than inhibin $\alpha$. 
An S100-positive immunoreaction was observed in all types of sex cord-stromal tumors. In our study (as controls), theca cell was positive for $\mathrm{S} 100$ (data not shown), and it was suggested that most sex cord-stromal tumors might have a cohort of theca cell element in the tissue. Also, the S100positive immunoreaction was thought to be a characteristic finding in sex-cord stromal tumors.

In germ cell tumors, a vimentin-positive immunoreaction was observed in many neoplastic cells, some with an AFP immunoreaction in addition. With the evidence that all kinds of ovary tumors investigated in the present study were positive for vimentin, it was suggested that vimentin might be the intermediate filament to form the most basic structure of the canine ovary. However, the poor reactivity to other immunohistochemistry except AFP may suggest that a germ cell tumor showed a low degree of differentiation. Germ cell tumors reportedly sometimes become PLAP-positive [5], but such an immunoreaction in a normal or neoplastic germ cell was not recognized in this study.

In addition, the present results indicated that malignancy of a tumor did not affect an immunohistochemical property. Further studies are needed for understanding the correlation between immunohistochemical property and tumor malignancy.

In conclusion, the present study served to elucidate the immunohistochemical characteristics of various histologic types in canine ovarian tumors. The immunohistochemical features of primary canine ovary tumors were mostly similar to those of the normal canine ovary. Canine ovarian tumors, because of their particular structures such as granulosa cell cord and/or cortical tubules, show complicated histology. Therefore, immunohistochemistry will be an effective tool to provide further characterization of their tumor types, especially when using PLAP, desmin and S100 besides cytokeratin $[1,7,9,12,14]$ and inhibin $\alpha[8,16]$, which have already been reported in human and/or dog. The present results may contribute to detailed understanding of the canine ovarian structure and to better aid in the diagnosis. Further histological characterization based on the morphology, just as in human cases, will also assist in proposing a proper strategy of the treatment.

ACKNOWLEDGEMENT. This study was supported by a grant-in-aid for the High Technological Reserch Center (Rakuno Gakuen University) from the Ministry of Education, Culture, Sports, Science and Technology of Japan.

\section{REFERENCES}

1. Gitsch, G., Kohlberger, P., Steiner, A., Neumeister, B. and Breitenecker, G. 1992. Expression of cytokeratins in granulosa cell tumors and ovarian carcinomas. Arch. Gynecol. Obstet. 251: 193-197.

2. Hurlimann, J.1994. Desmin and neural marker expression in mesothelial cells and mesotheliomas. Hum. Pathol. 25: 753757.

3. Kennedy, P.C. and Miller, R. B. 1993. The female genital system. pp. 358-370. In: Pathology of Domestic Animals, 4th ed.
(Jubb, K.V.F., Kennedy, P. C. and Palmer, N. eds.), Academic Press, San Diego.

4. Kennedy, P. C., Cullen, J. M., Edwards, J. F., Goldschmidt, M. H., Larsen, L., Munson, L. and Nielsen, S. 1998. Histological Classification of Tumors of the Genital System of Domestic Animals. 2nd series, vol. IV, WHO, AFIP, Washington, DC.

5. Lifschitz-Mercer, B., Walt, H., Kushnir, I., Jacob, N., Diener, P.A., Moll, R. and Czernobilsky, B. 1995. Differentiation potential of ovarian dysgerminoma: an immunohistochemical study of 15 cases. Hum. Pathol. 26: 62-66.

6. MacLachlan, N. J. 1987. Ovarian disorders in domestic animals. Environ. Health. Pers. 73: 27-33.

7. MacLachlan, N. J. and Kennedy, P. C. 1978. Tumors of the genital systems. pp. 547-557. In: Tumors in Domestic Animals, 4th ed. (Meuten, D. J. ed.), Iowa State Press, Iowa.

8. Marino, G., Nicotina, P. A., Catone, G., Bontempo, R. A. and Zanghi, A. 2003. Alpha-inhibin expression in canine ovarian neoplasms: preliminary results. Vet. Res. Commun. 27: 237 240.

9. McCluggage, W. G. and Young, R. H. 2005. Immunohistochemistry as a diagnostic aid in the evaluation of ovarian tumors. Semin. Diagn. Pathol. 22: 3-32.

10. McDicken, I. W., McLaughlin, P. J., Tromans, P. M., Luesley, D. M. and Johnson, P. M. 1985. Detection of placental-type alkaline phosphatase in ovarian cancer. Br. J. Cancer. 52: 5964.

11. McEntee, K. 1990. Ovarian neoplasms. pp. 66-93. In: Reproductive Pathology of Domestic Animals. Academic Press Inc., San Diego.

12. Moll, R., Levy, R., Czernobilsky, B., Hohlweg-Majert, P., Dallenbach-Hellweg, G. and Franke, W. W. 1983. Cytokeratins of normal epithelia and some neoplasms of the female genital tract. Lab. Invest. 49: 599-610.

13. Oliva, E., Alvarez, T. and Young, R. H. 2005. Sertoli cell tumors of the ovary: a clinicopathologic and immunohistochemical study of 54 cases. Am. J. Surg. Pathol. 29: 143156.

14. Patnaik, A.K. and Greenlee, P. G. 1987. Canine ovarian neoplasms: a clinicopathologic study of 71 cases, including histology of 12 granulosa cell tumors. Vet. Pathol. 24: 509-514.

15. Scully, R. E. 1977. Ovarian Tumors: A review. Am. J. Pathol. 87: $686-720$.

16. Shah, V. I., Freites, O. N., Maxwell, P. and McCluggage, W.G. 2003. Inhibin is more specific than calretinin as an immunohistochemical marker for differentiating sarcomatoid granulosa cell tumour of the ovary from other spindle cell neoplasms. $J$. Clin. Pathol. 56: 221-224.

17. Tavassoli, F. A. and Devilee, P. 2003. Tumours of the Ovary and Peritoneum. pp. 113-202. In: World Health Organization Classification of Tumours. Pathology and Genetics Tumours of the Breast and Female Genital Organs (Tavassoli, F. A. and Devilee, P. eds.), IARC Press, Lyon.WHO.

18. van de Voorde, A., Serreyn, R., de Boever, J., de Waele, P., Vandekerckhove, D. and Fiers, W. 1985. The occurrence of human placental alkaline phosphatase (PLAP) in extracts of normal, benign and malignant tissues of the female genital tract. Tumour. Biol. 6: 545-553.

19. Vos, J.H., van den Ingh, T.S., Misdorp, W., Ramaekers, F.C., van Mil, F. N. and de Neijs, M. 1989. An immunohistochemical study of canine tissues with vimentin, desmin, glial fibrillary acidic protein, and neurofilament antisera. Zentralbl. Veterinärmed. A. 36: 561-575. 